Journal of Healthcare Technology and Medicine Vol. 3 No. 2 Oktober 2017

Universitas Ubudiyah Indonesia

e-ISSN : 2615-109X

\title{
FAKTOR-FAKTOR YANG MEMPENGARUHI KEJADIAN STUNTING PADA BALITA DI WILAYAH KERJA PUSKESMAS BAITURRAHMAN KOTA BANDA ACEH
}

\author{
Factors Affecting The Stunting Events In Children In Baiturrahman Puskesmas \\ Working Area Banda Aceh City \\ Mira Abdullah *1, Elly Ratna Sari \\ Koresponding email : mira@uui.ac.id ${ }^{* 1}$, elly.sari@gmail.com² \\ Universitas Ubudiyah Indonesia
}

\begin{abstract}
Abstrak
Stunting atau pendek merupakan indikator status gizi kronis yang dapat menggambarkan pertumbuhan yang tidak optimal karena malnutrisi jangka panjang. Dinkes kota Banda Aceh menemukan prevelensi angka stunting pada balita di tahun 2016 menjadi 27,1\%. stunting pada balita di Kota banda Aceh masih menjadi masalah masyarakat. Tujuan Penelitian : Untuk mengetahui faktor-faktor yang mempengaruhi kejadian stunting pada balita di wilayah kerja puskesmas Baiturrahman Kota Banda Aceh tahun 2018. Metode Penelitian : Penelitian ini menggunakan desain case control dengan populasi yaitu seleuruh anak balita di wilayah kerja puskesmas Baiturrahman, total sampel adalah 53 balita sampel case dan 53 balita sampel control. Tehnik pengambilan sampel adalah teknik matching dan simple random sampling. Penelitian dilakukan pada tanggal 5 November - 9 Desember 2017. Cara pengumpulan data dengan metode wawancara. Selanjutnya dilakukan uji chi-square dengan tingkat kepercayaan $95 \%$ dan mencari nilai OR pada tabulasi $2 \times 2$. Ha diterima $p$ value <0,05. Hasil Penelitian : Dari hasil penelitian menunjukkan bahwa balita dengan asupan energi tidak adekuat dan mengalami stunting berjumlah 13 balita (24,5\%). Balita dengan asupan protein tidak adekuat dan mengalami stunting berjumlah 38 balita $(71,7 \%)$. Balita yang terkena penyakit infeksi dan mengalami stunting berjumlah 24 balita (45,3\%). Balita yang tidak memiliki riwayat ASI ekslusif berjumlah 35 balita (66\%). Balita yang memiliki riwayat BBLR dan mengalami stunting berjumlah 12 balita $(22,6 \%)$.Kesimpulan dan saran : Faktor yang mempengaruhi kejadian stunting pada balita adalah asupan protein $(p$ value $=0,000, O R=0,103)$, penyakit infeksi $(p$ value $=0,003, O R=$ 4,046), riwayat ASI ekslusif ( $p$ value $=0,011, O R=2,963), B B L R(p$ value $=0,026, O R=4,878)$. Asupan energi ( $p$ value $=0,816, O R=0,806$ ) bukan merupan faktor yang mempengaruhi kejadian stunting pada balita di wilayah kerja puskesmas Baiturrahman Kota Banda Aceh tahun 2018. Diharapkan Ibu balita untuk memperhatikan tumbuh kembang balita dengan pemenuhan asupan makanan sesuai kebutuhan, menjaga lingkungan dan membawa balita ke pelayanan kesehatan.
\end{abstract}

Kata Kunci : stunting, faktor pengaruh, balita

\begin{abstract}
Stunting or short is an indicator of chronic nutritional status that can describe growth that is not optimal due to long-term malnutrition. Banda Aceh City Health Office found the prevalence of stunting in children under five in 2016 to be 27.1\%. stunting on toddlers in the city of Aceh banda is still a public problem. Research Objectives: To determine the factors that influence the incidence
\end{abstract}


Journal of Healthcare Technology and Medicine Vol. 3 No. 2 Oktober 2017

Universitas Ubudiyah Indonesia

e-ISSN : 2615-109X

of stunting in toddlers in the Baiturrahman puskesmas working area in Banda Aceh City in 2018.

Research Method: This study uses a case control design with a population that is all children under five in the working area of the Baiturrahman puskesmas, the total sample is 53 toddlers sample cases and 53 toddlers control samples. The sampling technique is matching and simple random sampling techniques. The study was conducted on November 5 to December 9, 2017. The method of data collection was by interview method. Chi-square test was then performed with a $95 \%$ confidence level and look for the OR value in the $2 \times 2$ tabulation. Ha accepted p value $<0.05$. Results: The results showed that toddlers with inadequate energy intake and stunting amounted to 13 toddlers (24.5\%). Toddlers with inadequate protein intake and stunting amounted to 38 toddlers (71.7\%). Toddlers affected by infectious diseases and stunting amounted to 24 toddlers (45.3\%). Toddlers who do not have a history of exclusive breastfeeding totaled 35 toddlers (66\%). Toddlers who have a history of $L B W$ and stunting amounted to 12 toddlers (22.6\%) Conclusions and suggestions: Factors influencing the incidence of stunting in infants are protein intake ( $p$ value = $0,000, O R=0.103)$, infectious diseases ( $p$ value $=0.003$, OR $=4,046)$, history of exclusive breastfeeding ( $p$ value $=0.011, O R=2.963), L B W(p$ value $=0.026, O R=4.878)$. Energy intake ( $p$ value $=0.816, O R=0.806$ ) is not a factor affecting the incidence of stunting in infants in the area of Baiturrahman Puskesmas Banda Aceh City in 2018. It is expected that mothers of children under five will pay attention to the development of toddlers by fulfilling food intake as needed, protecting the environment and bringing toddlers to health services.

\section{Keywords: stunting, influence factors, toddlers}

\section{PENDAHULUAN}

Stunting atau pendek merupakan indikator status gizi kronis yang dapat menggambarkan pertumbuhan yang tidak optimal karena malnutrisi jangka panjang. Menurut Keputusan Menteri

Kesehatan Republik Indonesia tentang standar antropometri Penilaian Status Gizi (PSG) anak, pendek dan sangat pendek adalah status gizi yang didasarkan pada indeks panjang badan menurut umur $(\mathrm{PB} / \mathrm{U})$ atau tinggi badan menurut umur (TB/U). Z-score untuk kategori pendek adalah -3 SD sampai dengan <-2 SD dan sangat pendek adalah <-3 SD (Kemenkes RI, 2011).

Pemberian ASI yang baik oleh Ibu akan membantu menjaga keseimbangan gizi anak sehingga tercapai pertumbuhan anak yang optimal. Menurut penelitian di Manado yang dilakukan oleh Pengan, dkk (2015), riwayat pemberian ASI eksklusif pada anak usia 12-36 bulan beresiko 3,7 kali lebih besar terhadap terjadinya stunting.

BBLR merupakan prediktor penting dalam kesehatan dan kelangsungan hidup bayi yang baru lahir dan berhubungan dengan risiko tinggi pada anak (UNICEF, 2011). Berdasarkan penelitian yang dilakukan oleh Putra terdapat hubungan yang signifikan antara berat badan lahir rendah terhadap kejadian stunting pada anak usia 12-60. Anak yang memiliki berat badan lahir rendah berisiko sebesar 3 kali untuk menjadi stunting dibandingkan pada anak yang 
Journal of Healthcare Technology and Medicine Vol. 3 No. 2 Oktober 2017

Universitas Ubudiyah Indonesia

e-ISSN : 2615-109X

normal (Putra, 2016).

Stunting pada balita perlu menjadi perhatian khusus dan perlu dilakukan pemantauan karena dapat menghambat perkembangan fisik dan mental anak. Stunting berkaitan dengan peningkatan risiko kesakitan dan angka kematian serta mengakibatkan pertumbuhan yang tidak optimal, kemampuan motorik dan mental (Purwandini, K dan Kartasurya, M.I., 2016). Balita yang stunting memiliki risiko berupa penurunan kemampuan intelektual, produktivitas, dan peningkatan risiko penyakit degeneratif di masa yang akan datang (Anugraheni, H.S., 2012). Menurut Boggin, 1999 dalam Monica (2015) masa balita merupakan masa kritis dari pertumbuhan dan perkembangan dalam siklus hidup manusia. Masa ini juga di sebut masa keemasan dimana anak mengalami pertumbuhan yang sangat pesat. Oleh karna itu, baik buruknya status gizi balita pada masa ini akan berdampak langsung pada pertumbuhan dan perkembangan kognitif dan psikomotoriknya.

\section{METODE PENELITIAN}

Penelitian ini merupakan penelitian kuantitatif dengan desain case control, dimana desain ini bersifat retrospektif. Tujuannya adalah untuk mengetahui faktor yang mempengaruhi kejadian stunting pada balita di wlayah kerja Puskesmas Kopelma Darussalam Kota Banda Aceh tahun 2018 yang disebabkan oleh asupan energi, asupan protrin, penyakit infeksi (ISPA dan diare), riwayat ASI ekslusif, dan BBLR yang terjadi lebih dahulu.

\section{Kriteria kasus}

1. Kriteria inklusi

a) Balita yang memiliki nilai Z-score $<2$ SD dan dinyatakan stunting.

b) Bertempat tinggal di lokasi penelitian

c) Bersedia menjadi sampel penelitian

2. Kriteria ekslusi

a) Balita sedang menderita sakit infeksi atau kronis saat penelitian

b) Responden tidak berada di tempat selama penelitian setelah dua kali kunjungan berturut-turut.

\section{Kriteria kontrol}

1. Kriteria inklusi

a) Balita yang memiliki nilai Z-score - $2 \mathrm{SD}$ s/d >2 SD dan dinyatakan tidak stunting atau 
Journal of Healthcare Technology and Medicine Vol. 3 No. 2 Oktober 2017

Universitas Ubudiyah Indonesia

e-ISSN : 2615-109X

normal.

b) Bertempat tinggal di lokasi penelitian c) Bersedia

menjadi sampel penelitian

2. Kriteria ekslusi

a) Balita sedang menderita sakit infeksi atau kronis saat penelitian

b) Responden tidak berada di tempat selama penelitian setelah dua kali kunjungan berturut-turut.

\section{HASIL DAN PEMBAHASAN}

\section{Kejadian Stunting Pada Anak Balita}

Dalam penelitian ini diperoleh 45 balita yang mengalami stunting dan 45 balita yang normal dari total 90 sampel. Kejadian stunting pada balita dalam penelitian ini lebih banyak terjadi pada anak laiki-laki dikarenakan sebagian besar balita yang ada dijumpai saat penelitian berjenis kelamin laki-laki.

Hal ini sejalan dengan penelitian Lestari, Margawati dan Rahfiludin (2014) yang menyatakan bahwa kejadian stunting pada balita lebih banyak terjadi pada laki-laki $(50,7 \%)$ dari pada pada perempuan $(49,3 \%)$.

Stunting pada balita mengakibatkan kemampuan motorik dan mental yang tidak optimal (Purwandini, K dan Kartasurya, M.I., 2016). Stunting juga mengakibatkan anak tidak memiliki kepercayaan diri dan apatis (Nency dan Arifin, 2005). Pernyataan tersebut dibuktikan dari hasil penelitian. Dari 8 balita yang di ukur tinggi badan, 2 diantaranya menangis dan harus didampingi oleh ibunya saat dilakukan pengukuran. Keduanya merupakan balita yang mengalami stunting.

Hasil penelitian ini sesuai dengan penelitian yang dilakukan oleh Aridiyah, Rohmawati dan Ririyati tahun 2015, Asupan makanan bukan merupakan faktor terjadinya stunting. Adanya faktor lain seperti penyakit infeksi dan penyakit penyerta yang dapat mengganggu dan menghambat proses penyerapan energi dalam tubuh. Menurut penelitian Rahmaniah, Huriyati dan Irwanty (2014) dimana tidak ditemukan hubungan yang signifikan antara asupan energi dengan kejadian stunting pada balita. Penelitian lain juga mendapatkan hasil yang sama yaitu penelitian yang dilakukan oleh Anisa (2012) yang menyatakan bahwa asupan energi bukan termasuk penyebab kejadian stunting pada balita di kelurahan Kalibaru. Study dari Bangladesh 
Journal of Healthcare Technology and Medicine Vol. 3 No. 2 Oktober 2017

Universitas Ubudiyah Indonesia

e-ISSN : 2615-109X

dan Filiphina menunjukkan bahwa asupan energi seorang anak tidak terkait dengan pertumbuhan anak (Backer, black and brown; Bhargava dalam Stephenson et al, 2010).

\section{Pengaruh Asupan Protein Terhadap Kejadian Stunting Pada Balita}

Hal ini sejalan dengan penelitian Muclis, Hajhu dan Jafar (2011) yang menyatakan bahwa tidak terdapat hubungan antar asupan protein dengan status gizi TB/U dan BB/TB.

Berbeda penelitian dengan Anisa (2012) yang menyatakan bahwa terdapat hubungan yang bermakna antara asupan protein dengan kejadian stunting pada balita. Hal serupa dari hasil penelitian yang dilakukan oleh Madany (2017) bahwa terdapat hubungan antara asupan protein dengan kejadian stunting pada balita.

\section{Pengaruh Penyakit Infeksi Terhadap Kejadian Stunting Pada Balita}

Hal ini dapat disimpulkan bahwa ada pengaruh penyakit infeksi(ISPA atau diare) terhadap kejadian stunting pada balita. Anak yang menderita penyakit infeksi (ISPA atau diare) berisiko 4,343 kali lebih besar untuk menjadi stunting dibandangkan dengan anak yang tidak menderita penyakit infeksi (ISPA atau diare).

Hal ini sejalan dengan Penelitian Putra (2016) yang menyatakan bahwa terdapat pengaruh penyakit infeksi dengan kejadian stunting. anak yang mendapat penyakit infeksi berisiko 21 kali untuk menderita stunting. penelitian di Semarang oleh Ermawati dan Nuryanto (2016) diketahui bahwa penyakit infeksi dan asupan protein secara signifikan memiliki pengaruh terhadap kejadian stunting pada balita. Penelitian Priyono, Putri, Sulistiany dan Lersia. (2015) juga memperoleh hasil yang sajalan bahwa penyakit infeksi memiliki hubungan yang bermakna dengan kejadian stunting pada balita. Penyakit infeksi yang paling sering di derita yaitu ISPA dan diare.

Berbeda dengan penelitian Safitri dan Nindya (2017) yang menyatakan penyakit diare dan stunting tidak berhubungan secara signifikan. Asupan energi merupakan faktor lain yang menyebabkan kejadian stunting. Begitu pula dengan penelitian Hariany, Rohmawati dan Ningtiyas (2016) penyakit infeksi bukan merupakan faktor penyebab terjadinya stunting.

\section{KESIMPULAN}

1. Tidak ada pengaruh asupan energi terhadap kejadian stunting pada balita di wilayah kerja 
Journal of Healthcare Technology and Medicine Vol. 3 No. 2 Oktober 2017

Universitas Ubudiyah Indonesia

e-ISSN : 2615-109X

Puskesmas Kopelma Darussalam kota Banda Aceh dengan nilai $P$ value $(0,800)$ dengan nilai $\mathrm{OR}=1,294(0,477-3,510)$.

2. Tidak ada pengaruh asupan protein terhadap kejadian stunting pada balita di wilayah kerja Puskesmas Kopelma Darussalam dengan nilai $P$ value $(1,000)$ dengan nilai $\mathrm{OR}=1,112$ $(0,451-2,740)$.

3. Ada pengaruh penyakit infeksi terhadap kejadian stunting pada balita di wilayah kerja Puskesmas Kopelma Darussalam dengan nilai $P$ value $(0,006) \mathrm{OR}=4,343$ (1.601-11,779). Anak yang menderita penyakit infeksi berisiko 4,343 kali lebih besar untuk menjadi stunting dibandangkan dengan anak yang tidak menderita penyakit infeksi.

4. Ada pengaruh riwayat ASI ekslusif terhadap kejadian stunting pada balita di wilayah kerja Puskesmas Kopelma Darussalam kota Banda Aceh dengan nilai $P$ value $(0,057)$ dan OR $=2,480(1.060-5.803)$.

\section{DAFTAR PUSTAKA}

Anindita, P. 2012. Hubungan tingkat pendidikan Ibu, pendapatan keluarga, kecukupan protein dan seng dengan stunting pada balita usia 6-35 bulan. Jurnal Kesehatan Masyarakat. Vol 2. Hal 671-626.

Anshori, H A. 2013. Faktor risiko kejadian pada anak usia 12-14 bulan (studi di Kecamatan Semarang Timur). Universitas Diponegoro.

Anisa, Paramitha. 2012. Faktor-faktor yang berhubungan dengan kejadian stunting pada balita usia

25-60 bulan di kelurahan Kalibaru Depok tahun 2012. Univestas Indonesia.

Anugraheni, H. S. 2012. Faktor risiko kejadian stunting pada anak usia 12-36 bulan di kecamatan pati, kabupaten pati. Program Studi Ilmu Gizi Fakultas Kedokteran Universitas Diponegoro Semarang.

Almatsier, S. 2010. Prinsip Dasar Ilmu Gizi. Jakarta. Gramedia Pustaka Utama.

Amanda, Ameilia. 2014. Hubungan asupan zat gizi (energi, protein, zat besi dan seng), stunting dan psikososial denagn status motorik anak usia 3-6 tahun di PAUD wilayah binaan Puskesmas Kecamatan Kebayoran lama tahun 2014. Universitas Negeri Syarif Hidayatullah Jakarta.

Nadiyah, Briawan, Dodik dan Martianto, Drajat. 2008. Faktor risiko stunting pada anak usia 0-23 bulan di provinsi Bali, Jawa Barat dan Nusa Tenggara Timur. Jurnal Gizi dan Pangan. Vol.9 No.2 Hal.125-132.

Nasikhah, Roudhotun dan Margawati, Ani .2012. Faktor resiko kejadian stunting pada balita usia 24-36 bulan di Kecamatan Semarang Timur. Journal of nutrition college. Vol.1

No.1 Hal.176-184.

Ni'mah, Khoirun dan Nadhiroh, Siti Rahayu .2015. Faktor yang berhubungan dengan kejadian stunting pada Yunitasari L. 2012. Perbedaan intellegence quotion (IQ) antara anak stunting dan tidak stunting umur 7-12 tahun di Sekolah Dasar (studi pada siswa SD Negeri 
Journal of Healthcare Technology and Medicine Vol. 3 No. 2 Oktober 2017

Universitas Ubudiyah Indonesia

e-ISSN : 2615-109X

buara 04

Kecamatan Ketanggungan Kabupaten Brebes). Jurnal Kesehatan Masyarakat. Vol.1 No.2

Hal.586-595.

Purwandini, K. dan Kartasurya, M. 2013. Pengaruh pemberian mikronutrient sprinkle terhadap perkembangan motorik anak stunting usia 12-36 bulan. Journal Of Nutrition College. Vol.2 No.1 Hal.147-163.

Preedy VR. 2012. Handbook of growth dan growtg monitoring in health and disease. New York:

springer. Vol 1.

UNICEF. 2010. Penuntun Hidup Sehat - edisi 4. Jakarta : pusat promosi kesehatan Kementrian Kesehatan RI. Available at : www.factsforlifeglobal.org (di akses pada 20 januari 2018). 